\title{
INFLUENCE OF CHEMICAL COMPOSITION AND IMPURITIES ON MICROSTRUCTURE AND FORMATION OF INTERMETALLIC PHASES IN SELECTED ALUMINUM ALLOYS
}

\author{
José SENA, Jaromír DRÁPALA, Monika LOSERTOVÁ, Kateřina KONEČNÁ, \\ Gabriela KOSTIUKOVÁ
}

VSB - Technical University of Ostrava, Ostrava, Czech Republic, EU, jaromir.drapala@vsb.cz

https://doi.org/10.37904/metal.2020.3622

\begin{abstract}
Al-Si-Mg alloys account for the biggest percentage of cast pieces in the world and the automotive industry is one of major consumers of these alloys. The properties of Al alloys are influenced by their chemical composition, technology of casting, methods of forming and heat treatment. Alloying with $\mathrm{Sr}, \mathrm{Ti}$, B etc. can improve the structure of casts, the presence of $\mathrm{Fe}, \mathrm{Mn}$ leads to creation of intermetallic phases of $\mathrm{Al}_{x}(\mathrm{Fe}, \mathrm{Mn})_{y} \mathrm{Si}_{z}$ types. The experimental part complements this contribution with metallography and SEM/EDX analyses of three different specimens of cast Al alloys with and without heat treatment. Also, metallography results are given for Al profiles subjected to different working conditions. The mechanical properties of the cast alloys are evaluated by microhardness. The usability of Al-Si alloys with different elements in the automotive industry is demonstrated in this work.
\end{abstract}

Keywords: Aluminum alloys, chemical composition, microstructure, intermetallic phases, microhardness

\section{INTRODUCTION}

Aluminum is used in a wide range of vehicle parts ranging from heat exchangers to closures; each part requires unique functional properties for these differing automotive applications and therefore needs various alloying elements. The key alloying elements differ by alloy family. These additions can be $\mathrm{Cu}, \mathrm{Mn}, \mathrm{Si}, \mathrm{Mg}, \mathrm{Zn}$ and $\mathrm{Sn}$ $[1,2]$.

For simplification reasons, aluminum alloys have been divided in several categories. These categories are based on production types and compositions and the primary mechanism of mechanical properties development, with cast and wrought aluminum alloys based on production types and heat treatable and nonheat treatable based on the mechanism of properties development $[3,4]$.

The effect of different alloying elements in Al-Si alloys can improve certain properties making it suitable for a wide variety of uses. For a finer structure and improved electrical conductivity boron is used, while bismuth increases machinability and chromium improves hardenability. The addition of antimony increases corrosion resistance in sea water, but the addition of copper decreases this resistance while increasing the strength. Cobalt together with iron increases the alloy strength properties at high temperatures [4].

The benefits of alloying Al-Si castings with iron are the increase in hot-tear resistance and the decrease in the tendency of die soldering. This occurs when the molten aluminium welds to the die surface, damaging the die and resulting in a poor casting surface finish. At least $0.6 \mathrm{wt} \%$ of iron is required to avoid die sticking but higher iron concentration reduces the alloys fatigue properties. Iron also reacts to form several intermetallic phases like $\mathrm{FeAl}_{3}, \mathrm{FeMnAl}_{6}$ and $\alpha-\mathrm{AlFeSi}$. These phases are insoluble and are responsible for improvement in strength at elevated temperatures but come with the downside of embrittlement of the microstructure.

Iron also decreases the ability to feed, increases the porosity and diminishes the effect of grain refinement. Therefore, alloys such as A356 have a limit of $0.12 \mathrm{wt} \%$ of iron. Manganese is the most preferred element to 
neutralize the adverse effects of the excess of iron in the melt. Mn is typically added at half the percentage of iron in the melt. $\mathrm{Mn}$ and Fe may be considered isomorphous and alloy chemistry may reflect stoichiometries favouring the least detrimental insoluble Al-Fe-Mn phases [5,6].

When as-cast Al-Si alloys are subjected to elevated temperatures, they tend to experience growth due to the precipitation of silicon from the solid solution. Slow solidification of $\mathrm{Al}-\mathrm{Si}$ alloys results in a coarse microstructure, in which the eutectic comprises large plates or needles of silicon in the continuous matrix of aluminum. As the coarse plates of silicon are brittle, the eutectic alloy shows low ductility and tensile strength. Mechanical properties of Al-Si alloys are largely influenced by the size, form and distribution of second phase silicon particles, porosity, eutectic morphology and the grain structures. The second phase silicon particles affect the toughness, strength, ductility and tribological properties. Refinement of primary aluminum, silicon and eutectic mixture improves the mechanical properties.

Strontium modification effects are longer and the effective time can be extended up to 10 hours by adding 0.05 wt $\%$ to $0.2 \mathrm{wt} \%$ of beryllium, reducing the oxidation speed of the molten metal and stabilizing the strontium effect. High Sr master alloys should be added at the lowest practical temperature because they dissolve best at a low temperature $[4,7]$. Phosphorus with aluminum produces aluminum phosphide with a high melting point used as an active under-layer for the crystallization of primary $\mathrm{Si}$. The grain refinement is especially effective for hypoeutectic Al-Si alloys with a high proportion of solid a solution made available by adding $\mathrm{Ti}$ and $\mathrm{B}$ to the molten metal either individually or in a combination [4].

The microstructure of Al-Si alloys depends strongly on both the composition and the casting process. The rapid cooling causes a fine eutectic structure, small dendrites cells, small arm spacing and small grain size. Slower cooling rates require eutectic modification to obtain the finely dispersed eutectic silicon. The grain size and dendrite arm spacing are primarily controlled by cooling and solidification rates. Melt treatment, cooling conditions heat transfer from the solidifying metal to the mold has a significant influence on the eutectic morphology, thus playing an important role in obtaining a good casting quality [7].

The main goal of this work is the characterization of the microstructure and properties of three different aluminum alloys. Results of SEM/EDX analyses, incl. microhardness measurements, have been presented.

\section{EXPERIMENTAL MATERIAL AND RESULTS}

For the experimental study the following Al alloys have been used:

1) AlSi7Mg alloy, commonly referred to as A356, (sample no. 1) prepared by casting and heat treating

2) AISi12 eutectic alloy (sample no. 2) prepared by casting

3) AlSi10Mg alloy (sample no. 3) prepared by casting

4) AIMg0.7Si alloy profile with a $30 \times 30 \mathrm{~mm}$ area (sample no. 4) prepared by casting and forming

5) AlMg0.7Si alloy profile with a $60 \times 60 \mathrm{~mm}$ area (sample no. 5) prepared by casting and forming

The results of the chemical analyses of all the samples are presented in Table 1.

Table 1 Results of chemical analyzes by OES, average value from three measurements (wt\%)

\begin{tabular}{|c|c|c|c|c|c|c|c|c|c|c|c|}
\hline Specimen & Alloy & Si & Fe & Cu & Mn & Mg & Ti & B & Na & Sr & Al \\
\hline Sample no. 1 & AlSi7Mg & 7.24 & 0.152 & 0.001 & 0.004 & 0.287 & 0.115 & 0.002 & 0.001 & 0.017 & 92.2 \\
\hline Sample no. 2 & AlSi12 & 12.52 & 0.231 & 0.028 & 0,028 & 0.008 & 0.121 & --- & 0.003 & -- & 87.1 \\
\hline Sample no. 3 & AlSi10Mg & 13.67 & 0.940 & 0.710 & 0.288 & 0.58 & 0.052 & -- & $<0.001$ & --- & 84.0 \\
\hline Sample no. 4 & AlMg0.7Si & 0.36 & 0.190 & 0.007 & 0.052 & 0.350 & 0.009 & --- & $<0.001$ & --- & 99.0 \\
\hline Sample no. 5 & AlMg0.7Si & 0.42 & 0.200 & 0.006 & 0.052 & 0.450 & 0.012 & -- & $<0.001$ & --- & 98.8 \\
\hline
\end{tabular}


Figures $1 \mathrm{a}$ and $\mathbf{1 b}$ present the microstructures of samples no. 1 to no. 5 (the optical microscope).
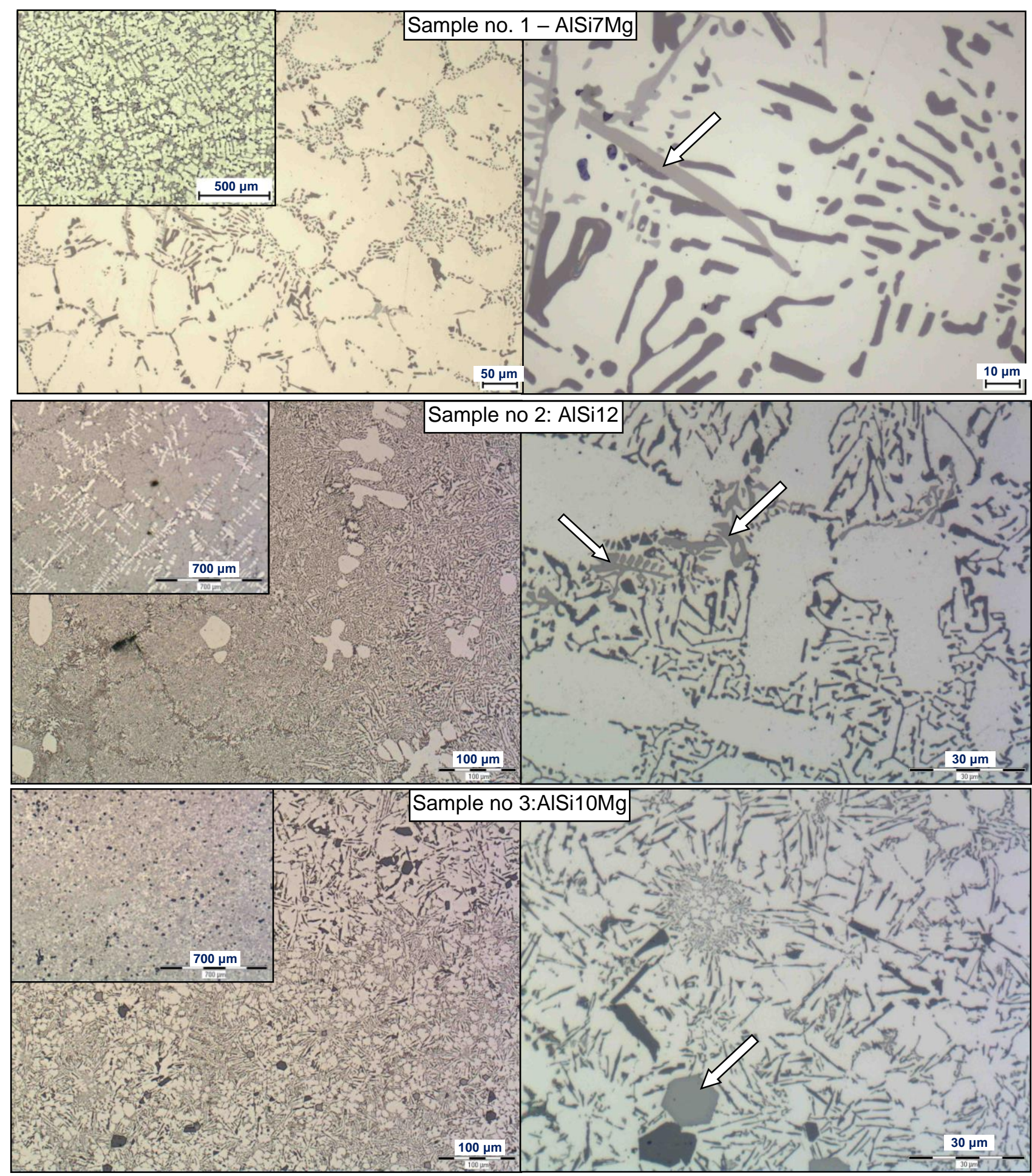

Figure 1a Microstructures of samples 1 to $3(\mathrm{OM})$

A356 (sample no. 1) is a heat treated and modified silumin that shows the primary aluminum dendrite structure embedded in Al-Si eutectic in a homogenized and well-organized dendritic structure. The structure contains a eutectic formed by needles of silicon in the Al solid solution. In sample no. 2 (AISi12) un-modified Al-Si eutectic in a form of thin dark needles of un-dissolved $\mathrm{Si}$ and primary crystallized $\mathrm{Al}$ dendrites are shown. The 
microstructure of sample no. 3 (AISi10Mg) is formed by the eutectic ( $\mathrm{Al}+$ thin needles of $\mathrm{Si}$ ) and bigger dark areas of pure silicon. In all three Al alloys the grey areas (needles, fish-bones or hexagons) are visible, which represent intermetallic phases containing probably $\mathrm{Fe}, \mathrm{Mn}, \mathrm{Al}$ and $\mathrm{Si}-$ see white arrows.

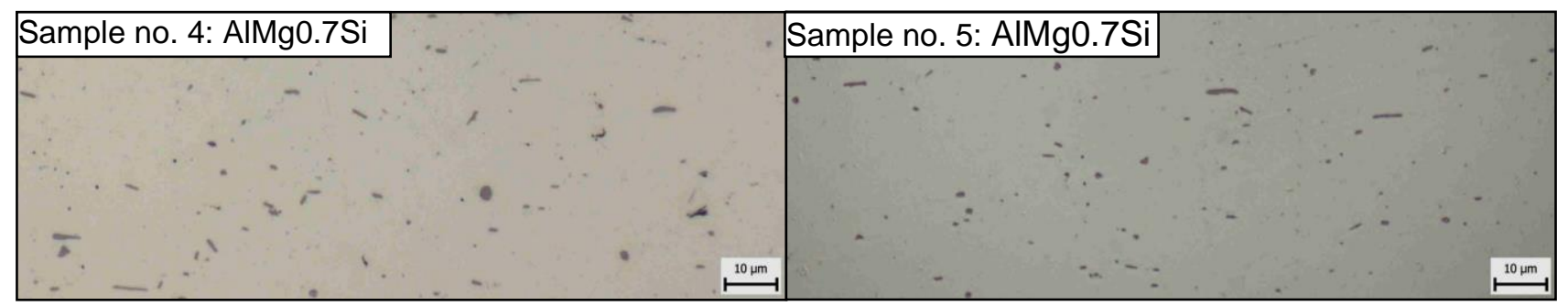

Figure 1b Microstructures of samples 4 and 5 - profiles $30 \times 30 \mathrm{~mm}$ and $60 \times 60 \mathrm{~mm}(\mathrm{OM})$

In samples no. 4 and no. 5) the matrix is pure aluminum, whereof little particles of another phase are visible.

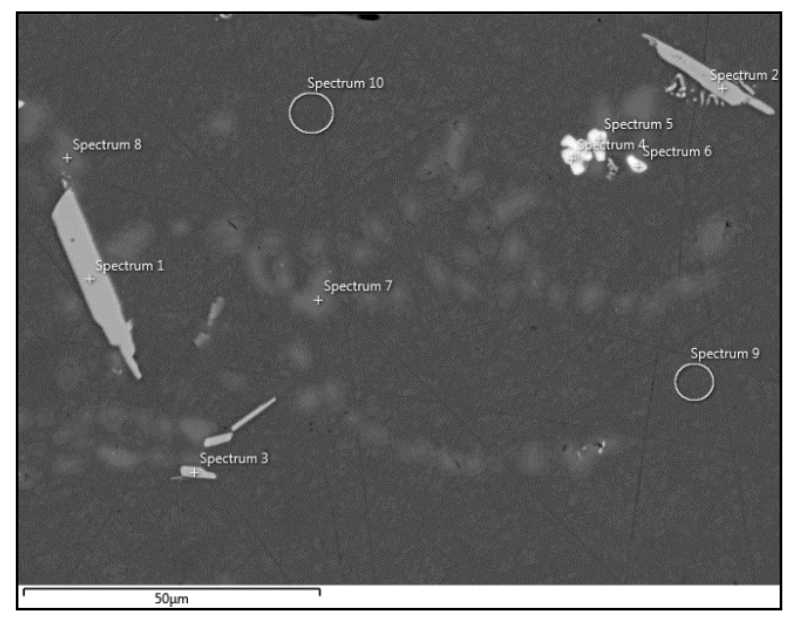

Table 2 Results of EDX chemical analyzes (at\%) sample no. 1 (AlSi7Mg)

\begin{tabular}{|l|c|c|c|c|c|c|c|c|}
\hline Label & $\mathbf{M g}$ & $\mathbf{A l}$ & $\mathbf{S i}$ & $\mathbf{C a}$ & $\mathbf{T i}$ & $\mathbf{M n}$ & $\mathbf{F e}$ & $\mathbf{S r}$ \\
\hline Spectra 1 - 3 & & 67.2 & 18.6 & & & 0.3 & 14.0 & \\
\hline Spectra 4 - 6 & 1.3 & 41.5 & 40.7 & 1.2 & 1.0 & & & 14.3 \\
\hline Spectra 7, 8 & & & 100.0 & & & & & \\
\hline Spectra 9, 10 & & 99.0 & 1.0 & & & & & \\
\hline
\end{tabular}

Figure 2 SEM/BEI microstructure of the sample no. 1 (AlSi7Mg) with positions of the EDX analysis (at\%)

Spectra 1, 2 and 3 are formed by sharp particles (Figure 2). The following types of phases have been known from literature: $\mathrm{Al}_{15}(\mathrm{Mn}, \mathrm{Fe})_{3} \mathrm{Si}_{2}, \mathrm{Al}_{12}(\mathrm{Mn}, \mathrm{Fe})_{3} \mathrm{Si}, \mathrm{Al}_{10}(\mathrm{Mn}, \mathrm{Fe}) 3 \mathrm{Si}, \mathrm{Al}_{9}(\mathrm{Mn}, \mathrm{Fe})_{2} \mathrm{Si}_{2}, \mathrm{Al}_{8}(\mathrm{Mn}, \mathrm{Fe})_{2} \mathrm{Si}, \mathrm{Al}_{5}(\mathrm{Mn}, \mathrm{Fe}) \mathrm{Si}_{2}$. In our case the most probable intermetallic compound is $\mathrm{Al}_{9}(\mathrm{Mn}, \mathrm{Fe})_{2} \mathrm{Si}_{2}$ with a theoretical proportion of atoms

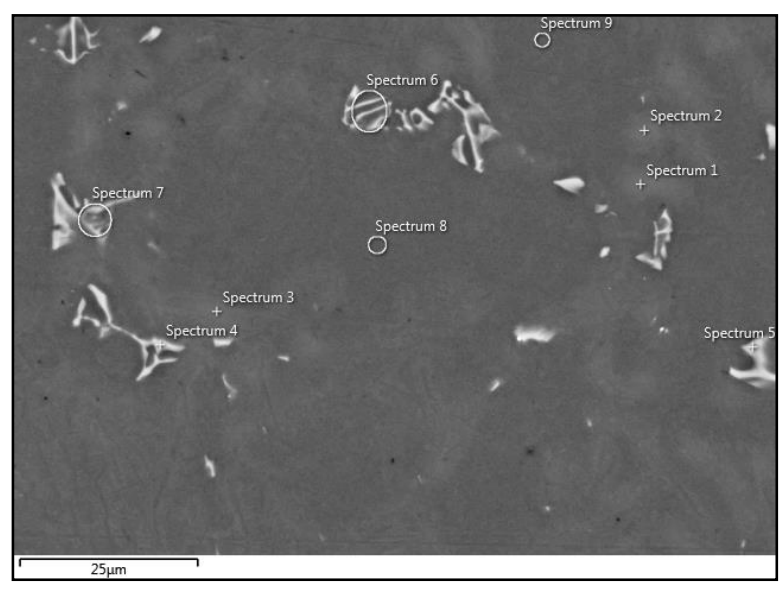

Figure 3 SEM/BEI microstructure of the sample no. 2 (AISi12) with positions of EDX analysis (at\%)
$\mathrm{Al}:(\mathrm{Mn}, \mathrm{Fe}): \mathrm{Si}=69.2: 15.4: 15.4$, which is in very good agreement with our results $\mathrm{Al}:(\mathrm{Mn}, \mathrm{Fe}): \mathrm{Si} \approx 68: 14: 18$. Fe and $\mathrm{Mn}$ are added to avoid the cast to stick to the die.

$\mathrm{Sr}$ is added for modification of the sharp structure usually present in the Al-Si eutectic, which changes to a more rounded form with less stress concentrator sites. Spectra 4,5 and 6 are created from globular light particles of IMC with Sr. There are currently four different phases associated to the intermetallic Al-Si-Sr composition: AlSiSr, $\mathrm{Al}_{2} \mathrm{Si}_{2} \mathrm{Sr}, \mathrm{Al}_{2} \mathrm{Si}_{2} \mathrm{Sr}_{3}$ and $\mathrm{Al}_{8} \mathrm{Si}_{15} \mathrm{Sr}_{4}$ [8]. In our case the ratio between atoms $\mathrm{Al}: \mathrm{Si}: \mathrm{Sr} \approx 41: 41: 14$, which corresponds approximately to the known intermetallic compounds $\mathrm{Al}_{2} \mathrm{Si}_{2} \mathrm{Sr}$. But the composition of the intermetallic compound may possibly be influenced by the presence of $\mathrm{Mg}, \mathrm{Ti}$ and $\mathrm{Ca}$ that were found in the spectrum. Ti is added for the grain refinement of the alloy 
and $\mathrm{Ca}$ have the same structure modification properties as $\mathrm{Na}$ with the added benefit of acting as a $\mathrm{Fe}$ neutralizer in recycled Al alloys with a high Fe content.

Table 3 Results of EDX chemical analyzes (at\%) sample no. 2 (AlSi12)

\begin{tabular}{|l|c|c|c|c|}
\hline Label & Al & Si & Mn & Fe \\
\hline Spectra 1-3 & 33.3 & 66.7 & & \\
\hline Spectra 4-7 & 89.5 & 6.3 & 0.4 & 3.8 \\
\hline Spectra 8-9 & 98.8 & 1.2 & & \\
\hline
\end{tabular}

Spectra 1, 2 and 3 correspond to Al-Si eutectic, where $\mathrm{Si}$ is concentrated. Spectra 4, 5, 6 and 7 are from bright areas, which belong to Al-Si-Mn-Fe phase. The exact determination of the formula for these particles is difficult in this case because of their small sizes and the influence of the eutectic surrounding. Spectra 8 and 9 are $(\alpha-A l)$.

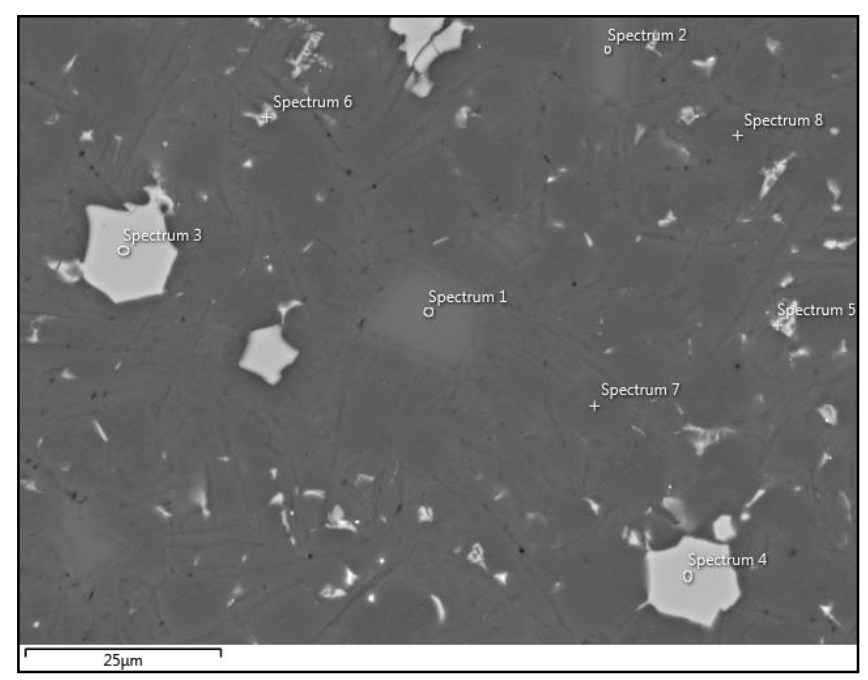

Table 4 Results of EDX chemical analyzes (at\%) sample no. 3 (AISi10Mg)

\begin{tabular}{|l|c|c|c|c|c|c|c|}
\hline Label & Al & Si & V & Cr & Mn & Fe & Cu \\
\hline Spectra 1 - 2 & 2.8 & 97.2 & & & & & \\
\hline Spectra 3 - 4 & 71.4 & 11.3 & 0.3 & 1.2 & 5.6 & 10.1 & 0.1 \\
\hline Spectra 5 - 6 & 82.0 & 10.4 & & & 1.2 & 5.2 & 1.3 \\
\hline Spectra 7 - 8 & 98.2 & 1.8 & & & & & \\
\hline
\end{tabular}

Figure 4 SEM/BEI microstructure of the sample no. 3 (AISi10Mg) with positions of EDX analysis (at\%)

Spectra 1 and 2 - bright grey areas and belong to almost pure $\mathrm{Si}$, un-dissolved $\beta$ phase. Spectra 3 and 4 are from bright areas, which belong to $\mathrm{Al}_{15}\left(\mathrm{Mn}, \mathrm{Fe}_{3} \mathrm{Si}_{2}\right.$ intermetallic compound. These particles contain all the alloying elements that give this alloy its properties. $\mathrm{V}$ and $\mathrm{Cr}$ are added to increase strength and $\mathrm{Cu}$ to help with the heat treatment of the alloy. Spectra 5 and 6 are marked in irregular sharp areas. These areas are composed by $\mathrm{Al}_{15}(\mathrm{Mn}, \mathrm{Fe})_{3} \mathrm{Si}_{2}$ with 1.3 at\% $\mathrm{Cu}$. Spectra 7 and 8 come from the $\alpha$-solid solution of aluminum.

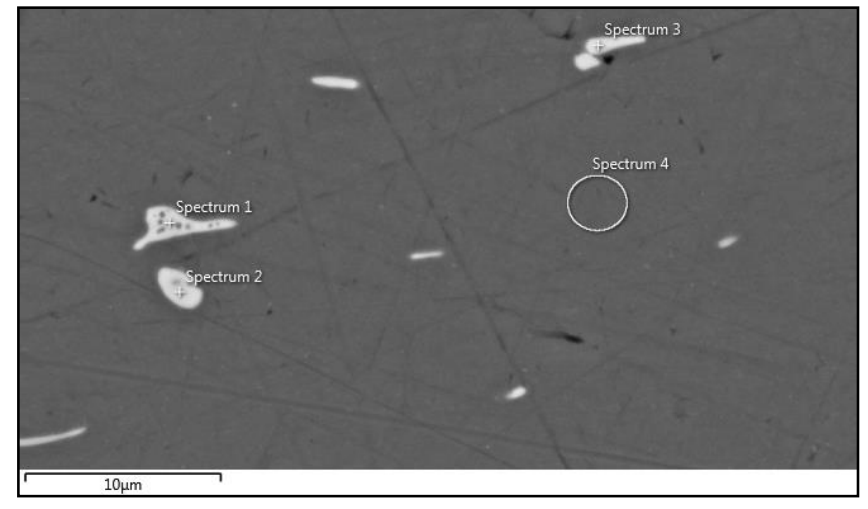

Table 5 Results of EDX chemical analyses (at\%) - sample no. 4 (Al profile)

\begin{tabular}{|l|c|c|c|c|c|}
\hline Label & Mg & Al & Si & Mn & Fe \\
\hline Spectra 1 - 3 & & 81.1 & 6.2 & 0.5 & 12.1 \\
\hline Spectrum 4 & 0.3 & 99.2 & 0.5 & & \\
\hline
\end{tabular}

Figure 5 SEM/BEI microstructure of sample no. 4 (Al profile) with positions of EDX analysis (at\%)

Spectra 1 to 3 belong to the bright irregular areas in the Figure 5, the chemical composition of these spots answers to intermetallic phase $\mathrm{Al}_{11}(\mathrm{Fe}, \mathrm{Mn})_{2} \mathrm{Si}$ type. Spectrum 4 is the $\alpha$-solid solution of aluminum with 0.5 at\% Si and 0.3 at $\% \mathrm{Mg}$.

In Table 6 results of HV microhardness measurements for all samples are presented. It is evident that the highest microhardness had the alloy AISi7Mg. 
Table 6 Microhardness results, average values from five measurements (HV 0.1)

\begin{tabular}{|c|c|c|c|c|c|}
\hline Sample & no.1 (AISi7Mg) & no. 2 (AISi12) & no. 3 (AISi10Mg) & no. 4 AlMg0.7Si $(30 \times 30)$ & no. 5 AlMg0.7Si (60 x 60) \\
\hline HV 0.1 & 109 & 66 & 95 & 73 & 80 \\
\hline
\end{tabular}

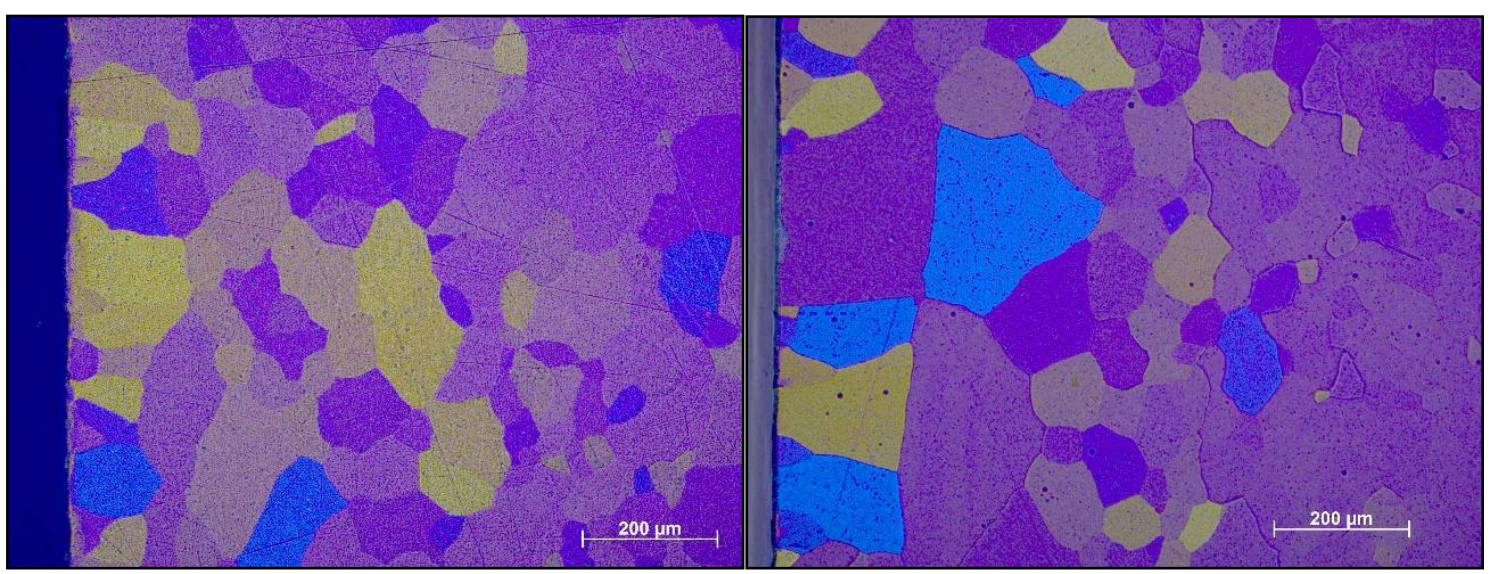

Figure 6 Grain structure in samples no. 4 (Al profile $30 \times 30$ - on the left) and no. 5 (Al profile $60 \times 60$ - on the right) - color etching

Figure 6 shows different grain sizes and their orientations. The average grain size for sample no. 4 was 69 $\mu \mathrm{m}$, for sample no. 5 is $60 \mu \mathrm{m}$, respectively. Near to the surface of the wall (thickness $3 \mathrm{~mm}$ ) grains are bigger than in the central part.

\section{CONCLUSIONS}

This work deals with three different types of aluminum alloys AISi7Mg (A356) after casting and heat treatment; AISi12 and AISi10Mg only after casting and alloys AIMg0.7Si (profiles $30 \times 30 \mathrm{~mm}$ and $60 \times 60 \mathrm{~mm}$ ) after forming. On the basis of EDX analyses we have found three types of intermetallic compounds: $\mathrm{Al}_{9}(\mathrm{Mn}, \mathrm{Fe})_{2} \mathrm{Si}_{2}$ in $\mathrm{A} 356, \mathrm{Al}_{15}(\mathrm{Mn}, \mathrm{Fe})_{3} \mathrm{Si}_{2}$ in the alloy $\mathrm{AlSi10Mg}$ and $\mathrm{Al}{ }_{11}(\mathrm{Fe}, \mathrm{Mn})_{2} \mathrm{Si}$ type in the AlMg0.7Si profiles. In A356 alloyed with strontium we have found $\mathrm{Al}_{2} \mathrm{Si}_{2} \mathrm{Sr}$ intermetallic phases. The highest microhardness has been observed in AISi7Mg alloy. The microstructure of all three Al-Si-Mg alloys has been dendritic ( $\alpha$ - solid solution of $\mathrm{Al}$ ) with the eutectic $(\mathrm{Al})+(\mathrm{Si})$ in a form of thin Si needles. The substructure of Al profiles has shown grains with different sizes and orientations, the average grain size has been between 50 and $70 \mu \mathrm{m}$.

The automotive and aerospace industry have been using these alloys for a long time and thousands of articles have been written already studying their properties, proposing not only technological changes to the way the alloys are processed but also changes in processing the castings and in the amount of alloying elements.

\section{ACKNOWLEDGEMENTS}

This work was solved in the frame of the project "Preparation and optimalization of properties of alloy for automotive, electrotechnic and biomedical applications" - project No. SP2020/56.

\section{REFERENCES}

[1] HIRSCH, J. Recent development in aluminum for automotive applications. Transactions of Nonferrous Metals Society of China. 2014, vol. 24, no. 2014, pp. 1995-2002.

[2] AROWOSOLA, A. GAUSTAD, G. Estimating increasing diversity and dissipative loss of critical metals in the aluminum automotive sector. Resources, Conservation \& Recycling. 2019, vol. 1050, no. 150, pp. 104-114.

[3] DAVIS, J. R. ASM Specialty Handbook: Aluminum and Aluminum Alloys. Ohio: ASM International, 1993. 
[4] MICHNA, Š. et al. Aluminum Materials and Technologies from A to Z. Prešov: ADIN, 2007.

[5] NATH, J. Aluminum Casting Engineering Guide. Ohio: ASM International, 2018.

[6] GILBERT KAUfMAN, J., ROOY, E. L. Aluminium Alloy Castings: Properties, Processes, and Applications. Ohio: ASM International, 2004.

[7] HEGDE, S., NARAYAN PRABHU, K. Modification of eutectic silicon in Al-Si alloys. Journal of Material Sciences. 2008, vol. 43, no. 9, pp. 3009-3027.

[8] GARAY-TAPIA, A. M., ROMERO, A. H., TRAPAGA, G., ARRÓYAVE, R. First-principles investigation of the AI-SiSr ternary system and determination and mechanical properties. Intermetallics. 2012, no. 21, pp. 31-44. 